ORNL/TM-2006/592

ORNL/SUB/06-4000049375

\title{
2006 UPDATE OF BUSINESS DOWNTIME COSTS
}

\author{
A WHITE PAPER FOR THE \\ OFFICE OF ELECTRICITY \& ENERGY DELIVERY'S \\ DISTRIBUTED ENERGY PROGRAM
}

\section{DECEMBER 2006}

\author{
Douglas Hinrichs and Michael Goggin \\ SENTECH, Inc. \\ Bethesda, MD 20814
}

\author{
Sponsored by \\ U.S. Department of Energy \\ Office of Electricity Delivery \& Energy Reliability \\ Distributed Energy Program
}

OAK RIDGE NATIONAL LABORATORY

Oak Ridge, Tennessee 37831

Managed by

UT-BATTELLE, LLC

For the

U.S. Department of Energy

Under Contract No. DE-AC05-00OR22725 


\section{ACKNOWLEDGEMENT}

The authors wish to thank Patti Garland, David Stinton, and Therese Stovall for their support and technical review of this paper 


\section{TABLE OF CONTENTS}

EXECUTIVE SUMMARY

I. BACKGROUND

A. Business Downtime Costs and the Value of Onsite Energy 4

B. Factors to Consider when Discussing Downtime Costs 4

1. Downtime Cost Components 4

2. Business Type 5

3. Power Outage Duration 5

II. METHODOLOGY 6

A. Data Sources $\quad 6$

B. Data Analysis 6

C. Data Limitations $\quad 7$

III. RESULTS $\quad 8$

A. Average Establishment Results $\quad 8$

B. Change in Downtime Costs over the Duration of a Power Outage 8

C. Comparison of Results to Those of Other Published Reports 9

D. Comparison of Results to Available Market Data $\quad 12$

1. California Refrigerated Warehouse Market $\quad 12$

2. Michigan Food Retail Market 14

IV. CONCLUSIONS $\quad \mathbf{1 5}$

A. Downtime Cost Components 15

B. Business Type 15

C. Power Outage Duration 16

D. Implications for Onsite Energy for Greater Business Continuity 18

$\begin{array}{ll}\text { APPENDIX } & 20\end{array}$

$\begin{array}{lr}\text { END NOTES } & 23\end{array}$ 


\section{EXECUTIVE SUMMARY}

The objective of this paper is to assess the downtime cost of power outages to businesses in the commercial and industrial sectors, updating and improving upon studies that have already been published on this subject. The goal is to produce a study that, relative to existing studies, 1) applies to a wider set of business types 2) reflects more current downtime costs, 3) accounts for the time duration factor of power outages, and 4) includes data on the costs imposed by real outages in a well-defined market.

This study examines power outage costs in 11 commercial subsectors and 5 industrial subsectors, using data on downtime costs that was collected in the 1990's. This study also assesses power outage costs for power outages of 20 minutes, 1 hour, and 4 hours duration. Finally, this study incorporates data on the costs of real power outages for two business subsectors.

However, the current limited state of data availability on the topic of downtime costs means there is room to improve upon this study. Useful next steps would be to generate more recent data on downtime costs, data that covers outages shorter than 20 minutes duration and longer than 4 hours duration, and more data that is based on the costs caused by real-world outages. Nevertheless, with the limited data that is currently available, this study is able to generate a clear and detailed picture of the downtime costs that are faced by different types of businesses. 


\section{BACKGROUND}

\section{A. Business Downtime Costs and the Value of Onsite Energy}

The distributed, renewable, and fuel cell energy communities have frequently cited "business downtime costs" from Table 1, "Selected Outage Costs," when discussing the value that power reliability and quality from onsite energy generation can provide to building owners.

Table 1. Selected Outage Costs

\begin{tabular}{|l|c|l|}
\hline \multicolumn{1}{|c|}{ INDUSTRY } & AVERAGE COST OF DOWNTIME & \multicolumn{1}{c|}{ SOURCE } \\
\hline Cellular Communications & $\$ 41,000$ per hour & Teleconnect Magazine \\
\hline Telephone Ticket Sales & $\$ 72,000$ per hour & Contingency Planning Research-1996 \\
\hline Airline Reservations & $\$ 90,000$ per hour & Contingency Planning Research-1996 \\
\hline Credit Card Operations & $\$ 2,580,000$ per hour & Contingency Planning Operations-1996 \\
\hline Brokerage Operations & $\$ 6,480,000$ per hour & Contingency Planning Operations-1996 \\
\hline
\end{tabular}

These downtime cost data, although extensively cited, have limited applicability to many building owners in 2006 for several reasons. First, downtime costs are provided for only five industry types - ones that typically need high degrees of power reliability and quality. Also, the table's downtime costs are listed as an average hourly rate with no consideration given to the duration of a power outage. From the data presented, it is not clear if these outage costs only account for lost revenue, or if they include other costs that can be caused by power outages such as damaged equipment and lost product. Finally, the original sources from which this information was gathered were published in 1996, raising the possibility that these costs are out of date due to technological changes that have occurred in the U.S. economy.

Attempts to contact Teleconnect Magazine, Contingency Planning Research, and Contingency Planning Operations to better understand their data were not successful. Thus, alternative methods are needed to update and possibly improve upon these downtime cost data.

The objective of this paper is to assess the cost of power outages to businesses in the commercial and industrial sectors using the best and most current data available, short of surveying a statistically significant pool of building owners. Using existing studies, a compilation can be made of data that 1) applies to a wider set of "industry" types 2) reflects more current downtime costs, 3) accounts for the time duration factor of power outages, and 4) includes the range of costs imposed by real-world outages in a well-defined market.

This assessment is more aligned with the growing business trend of "business continuity planning." According to KPMG - an international firm that provides information risk management, audit, tax, and advisory services to businesses worldwide ${ }^{1}$ - companies are developing continuity plans that prepare their firms for power quality or outage events lasting from milliseconds to entire days. Since downtime can be costly and even force companies out of business, KMPG advises clients to focus on ensuring financial continuity, customer satisfaction, and productivity despite a catastrophe. ${ }^{2}$

\section{B. Factors to Consider when Discussing Downtime Costs}

To accurately assess the costs of downtime and to make an update of downtime costs that is useful to a wide spectrum of business types, it is essential to identify and consider data on how the following factors affect downtime costs:

1. Downtime Cost Components. Lost revenue is the most visible and easily identified cost of downtime, yet there are many other tangible and intangible impacts that must be factored into calculating a company's total downtime costs: 
a. Tangible cost components can be identified and measured in terms of hard dollars and may include equipment damage, electronic data loss, lost revenue, lost productivity, idle labor and facilities, inventory damage, late fees and penalties, repair and ramp-up costs ${ }^{3}$-as illustrated in Figure 1.

b. Intangible cost components are more difficult to ascertain and quantify but may include market perception of the company, stock losses, and lost opportunities ${ }^{4}$-as illustrated in Figure 1.

Figure 1: Cost Components of Business Downtime

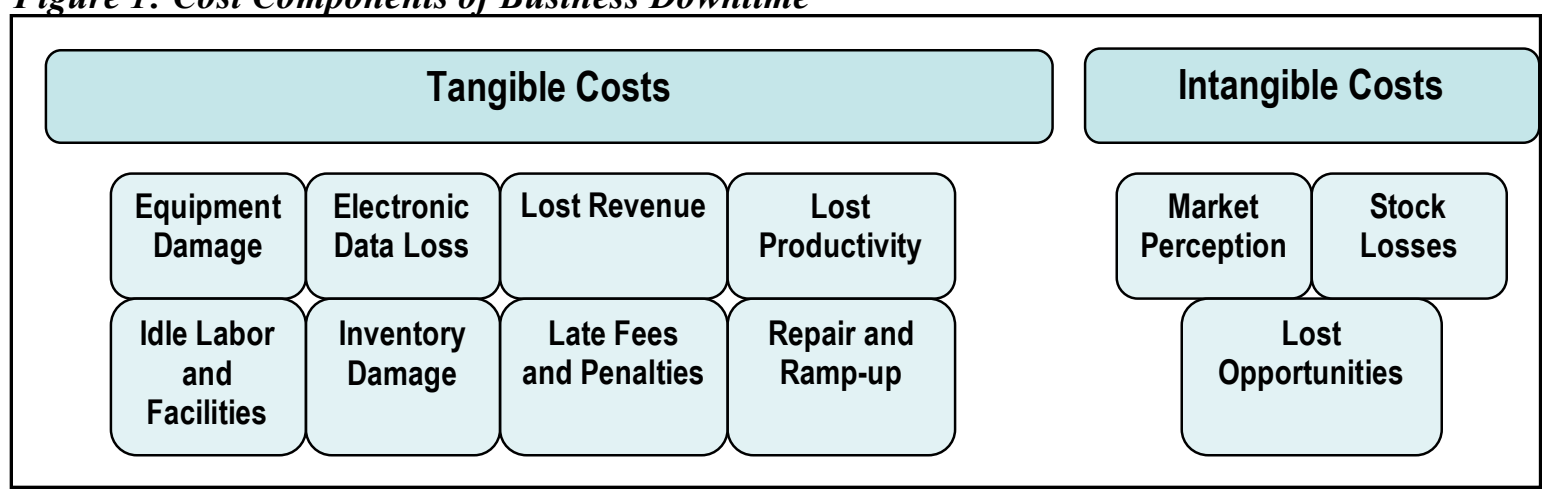

2. Business Type. The downtime costs for the five business types included in Table 1 account for only a fraction of the total economy-wide costs of a power outage. In addition, because some types of businesses are more sensitive to power outages than others, outage costs vary drastically from one subsector of the economy to another.

This paper examines outage costs for a broad range of businesses in the commercial and industrial sectors, using published reports, personal contacts, and databases. Sources include the U.S. Census Bureau's North American Industry Classification System (NAICS), DOE's Commercial Buildings Energy Consumption Survey (CBECS), researchers at the National Laboratories, business analysts such as KPMG, and think tanks such as the Uptime Institute.

3. Power Outage Duration. Published discussions of electricity interruption costs frequently assume that downtime costs stay the same over the duration of an outage. However, many reports and data show that downtime costs change significantly over the duration of an outage, making simple dollar per hour cost figures inaccurate and imprecise.

A study by Lawrence Berkeley National Laboratory, for example, shows that marginal outage costs to large commercial and industrial businesses tend to increase as the outage duration increases from one to eight hours. ${ }^{5}$ However, some businesses experience the greatest damage in the first seconds or even milliseconds of a power interruption. Traditionally, businesses have planned for natural or man-made disasters disrupting production, distribution and data processing in the power reliability timescale, i.e. seconds to minutes. Now, the economics of information, globalization, and technology has put new impetus on businesses planning for power quality events - voltage sags, power blips, or out-of-synch events lasting from milliseconds to two seconds - that affect sensitive equipment such as computers and processors. 


\section{METHODOLOGY}

The goal of this analysis is to obtain annual downtime costs for various subsectors of the economy for outages of different durations. The following methodology lays the groundwork for how this report assesses business downtime costs using select data and reports.

\section{A. Data Sources}

After a careful examination of several potential sources of data on downtime costs, one study was identified-“"Electrical Power Interruption Cost Estimates for Individual Industries, Sectors, and U.S. Economy" - that satisfied the three factors to consider when discussing downtime costs noted above. Namely, the study:

1. Is based on an end-user survey method designed to capture many of the tangible costs of downtime,

2. Considered a large number (70) of business types, and

3. Contained cost data for power outages of varying duration.

This electrical power interruption cost estimate study was written by Balducci et al. and published by Pacific Northwest National Laboratory (PNNL) in 2002 (hereinafter referred to as the "Balducci study"), and was based on a survey that covered outages of 20 minutes, 1 hour, and 4 hours in duration. Because this data is based on surveys from actual end-users, they capture costs including:

- Lost revenue,

- Lost production,

- Idle facilities and labor,

- Damage to electronic data,

- Damaged or spoiled product,

- Damage to equipment, and

- Customer refunds.

Intangible costs were judged to be too difficult-and too dependent on factors unique to individual businesses-to quantify in general terms.

\section{B. Data Analysis}

The Balducci study expresses downtime costs in the unit of dollars per peak annual kilowatt of electricity used by a facility. To make the Balducci data more useful for businesses, this data was combined with publicly available information to calculate average downtime costs for individual businesses and for aggregate sectors of the economy.

The survey data for the Balducci study were initially collected by the University of Saskatchewan in 1991 and 1995, and were published in 1996. The survey responses are divided into 70 subsectors of the commercial and industrial sectors and the residential sector, and list costs for 20-minute, 1-hour, and 4hour outages.

For this paper's analysis, the dollars per peak annual kilowatts $(\mathrm{kW})$ unit was converted to dollars per annual kilowatt-hours $(\mathrm{kWh})$, using the ratio of 1 peak $\mathrm{kW}$ equals 2000 annual $\mathrm{kWh}$, as inferred from the values listed for the Saskatchewan 1991 study in Eto et al., 2001. ${ }^{7}$ This ratio was calculated by comparing the reported dollars per peak $\mathrm{kW}$ cost with the reported dollars per annual $\mathrm{kWh}$ cost for the commercial sector. This ratio was also used for the industrial sector because, for outages of different durations, there are inconsistencies in the ratio between reported $\$ / \mathrm{kW}$ and $\$ / \mathrm{kWh}$ costs for the industrial sector, and because the ratio for the industrial sector was comparable to 1:2000 for most outage durations. The value for each subsector was then converted from 1996 dollars to 2006 dollars using a conversion factor of 
1.285, obtained from an inflation conversion calculator based on the Consumer Price Index made available by the University of Oregon. ${ }^{8}$

Next, the number of kWh's annually consumed by each subsector of the commercial and industrial sectors in the United States was identified. Energy use data for the industrial subsectors for 1996 are published in the Balducci study. Because the level of industrial electricity consumption in the U.S. in 2003 is nearly identical to what it was in 1996, it was not adjusted to estimate current costs. ${ }^{9}$ The number of $\mathrm{kWh}$ of electricity consumed by each commercial subsector in 2003 was obtained from EIA's Commercial Buildings Energy Consumption Survey (CBECS) database.

For the most part, the commercial subsectors listed in CBECS directly translate to subsectors for which downtime cost data is available in the Balducci study. However, the Balducci study lists both a "personal services" subsector and a "business services" subsector, while CBECS only lists a "services" subsector. To resolve this, the assumption was made that the CBECS "services" category was comprised of one-half business services and one-half personal services.

The outage cost per annual $\mathrm{kWh}$ for each subsector was then multiplied by the number of annual $\mathrm{kWh}$ 's used by that subsector to obtain a cost for a 20 minute, 1 hour, and 4 hour power outage for that subsector. The subsector costs were then aggregated to calculate the cost of an outage for each major sector and for the entire U.S. economy. The subsector cost results are shown in an appendix to this report. Finally, by obtaining the number of establishments in each industrial subsector from NAICS data and in each commercial subsector from the CBECS data, it was possible to calculate the costs of business downtime for the average establishment in each subsector.

\section{Data Limitations}

The largest drawback to using the Balducci data is that it was collected in 1991 and 1995. However, more recent data of adequate comprehensiveness, detail, or accuracy is not available. It is likely that the U.S. economy's vulnerability to power outages has changed to some extent over the past decade as technology has changed. In particular, increased use of technologies like computers and the Internet may have made the economy more vulnerable to power interruptions. Unfortunately, it is extremely difficult to accurately quantify the impact of that change.

Another potential source of uncertainty is that, because the Balducci data was collected in Canada, it may not be an entirely accurate representation of outage costs for the United States economy. In particular, greater reliance on air conditioning in the United States may lead to higher outage costs in this country. Overall, variations in outage costs caused by technological differences between the economies of the United States and Canada are likely to be small.

A final drawback is that the Balducci data does not cover momentary power interruptions shorter than 20 minutes and sustained outages longer than 4 hours. Several studies have documented that momentary power interruptions make up a large share of outage costs in the United States, largely because there is an average of 4.3 momentary interruptions per year compared to 1.2 sustained outages. ${ }^{10}$ However, based on this paper's cost results for 20 minute outages, one can get a sense of the costs imposed by momentary outages. Ultimately, the Balducci data was found to be the best source for making an accurate and comprehensive assessment of business downtime costs. 


\section{RESULTS}

Results on the costs of downtime to average establishments in certain business subsectors are discussed below. As a validity check, these results are then compared to expected patters, other related reports, and to actual market data from two smaller, well-defined markets.

\section{A. Average Establishment Results}

Table 1, referenced at the beginning of this study, provided the onsite generation community with useful statistics to inform discussions of the benefits of higher power reliability and quality. The results of this study will hopefully prove similarly useful to the onsite generation community, government agencies, and real-world end-users who may be interested in investing in and realizing the benefits of higher power reliability and quality from onsite generation. To that end, data on the costs of business downtime for typical establishments in select commercial and industrial subsectors are presented in Table 2. With the notable exception of the refrigerated warehouse subsector, it can generally be stated that typical establishments in the industrial subsectors lose more money per unit of time from electricity outages than typical establishments in the commercial subsectors.

Table 2: Cumulative Cost of Business Downtime per Average Establishment in Select Subsectors

\begin{tabular}{|c|c|c|c|}
\hline Commercial Subsector & 20 minutes & 1 hour & 4 hours \\
\hline Non-Refrigerated Warehouses & $\$ 118$ & $\$ 189$ & $\$ 399$ \\
\hline Refrigerated Warehouses & $\$ 7,710$ & $\$ 23,100$ & $\$ 120,000$ \\
\hline Food sales & $\$ 1,680$ & $\$ 5,040$ & $\$ 26,200$ \\
\hline Food service & $\$ 1,290$ & $\$ 3,870$ & $\$ 20,200$ \\
\hline Mercantile & $\$ 227$ & $\$ 1,670$ & $\$ 4,890$ \\
\hline Lodging & $\$ 128$ & $\$ 353$ & $\$ 952$ \\
\hline Service & $\$ 488$ & $\$ 1,040$ & $\$ 3,090$ \\
\hline Health care & $\$ 865$ & $\$ 1,100$ & $\$ 1,590$ \\
\hline Offices & $\$ 392$ & $\$ 497$ & $\$ 721$ \\
\hline Education & $\$ 55$ & $\$ 206$ & $\$ 779$ \\
\hline Public Order & $\$ 777$ & $\$ 1,290$ & $\$ 3,050$ \\
\hline Industrial Subsector & 20 minutes & 1 hour & 4 hours \\
\hline Food and Kindred Processes & $\$ 6,440$ & $\$ 20,500$ & $\$ 68,700$ \\
\hline Chemicals and Allied Products & $\$ 12,400$ & $\$ 23,800$ & $\$ 131,000$ \\
\hline Primary Metal Industries & $\$ 27,400$ & $\$ 44,100$ & $\$ 93,100$ \\
\hline Industrial Machinery & $\$ 16,200$ & $\$ 29,000$ & $\$ 99,000$ \\
\hline Transportation Equipment & $\$ 20,500$ & $\$ 50,500$ & $\$ 395,000$ \\
\hline
\end{tabular}

\section{B. Change in Downtime Costs over the Duration of a Power Outage}

The results of this study indicate that downtime costs do change over the duration of a power outage. Some subsectors experience their highest costs in the initial minutes of an outage, while other subsectors face low costs initially but experience high costs if an outage persists for a longer period of time. Figures 2 and 3 illustrate how downtime costs change over the duration of a power outage for different subsectors. Costs are given on a cumulative average dollar per minute basis, so an upward-sloping line indicates that $\$ /$ minute costs increase over time while a downward-sloping line indicates that $\$ /$ minute costs decrease over time. In Figure 2, costs are presented on a logarithmic scale. 
Figure 2: Downtime Costs per Minute for Average Establishments in Select Commercial Subsectors

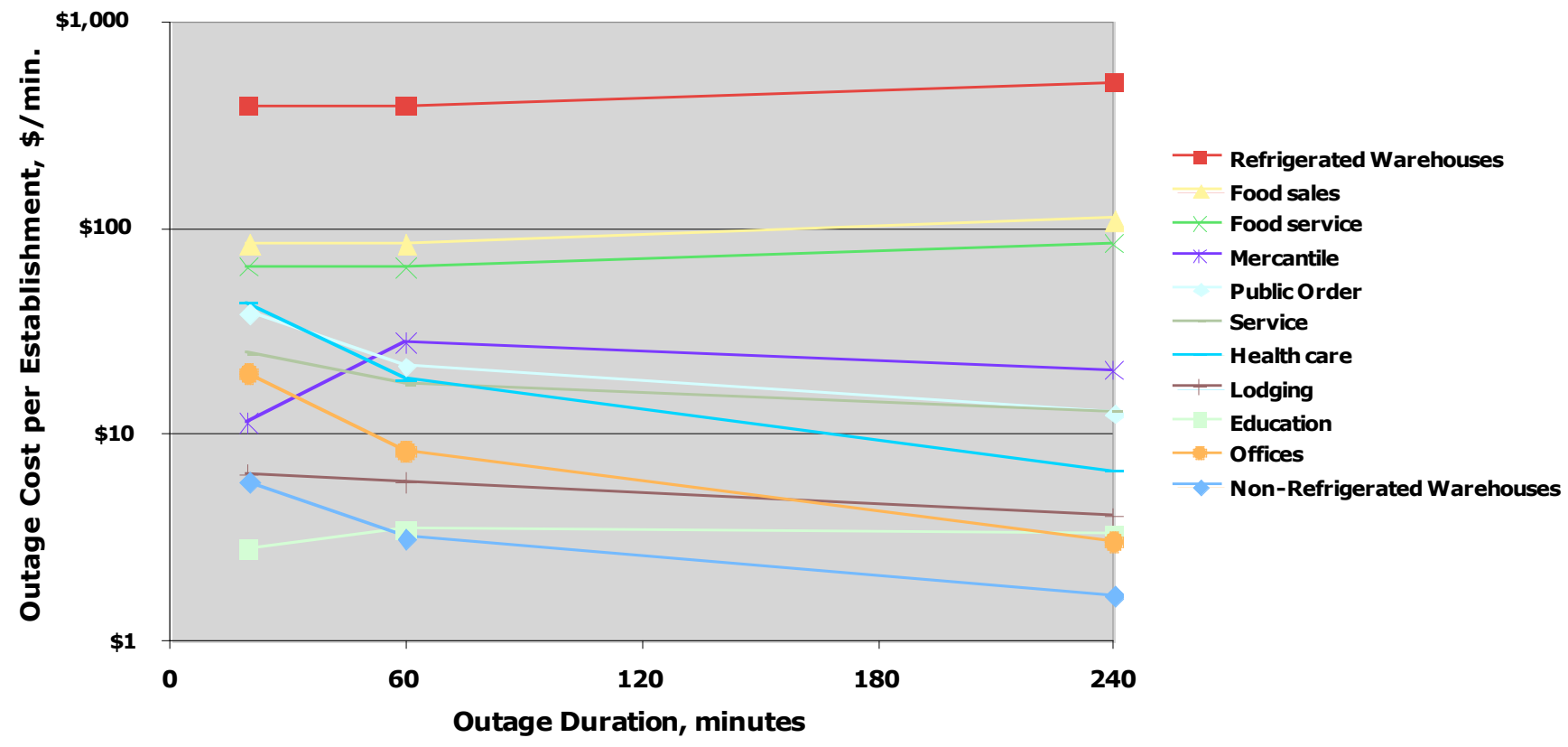

Figure 3: Downtime Costs per Minute for Average Establishments in Select Industrial Subsectors

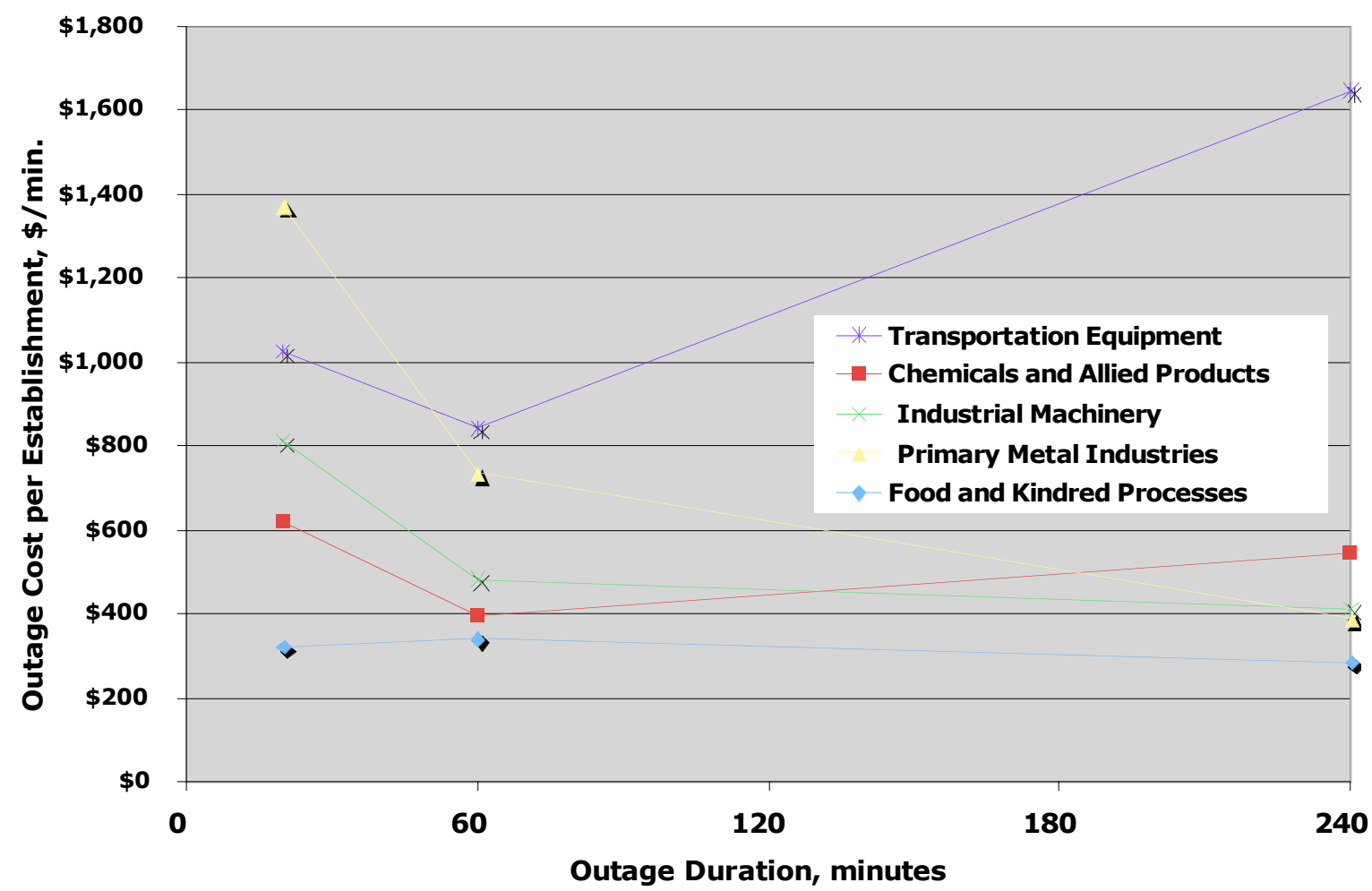

\section{Comparison of Results to Those of Other Published Reports}

The Balducci study was chosen as the basis for this analysis because it includes data on a large number of subsectors, incorporates the outage duration element, and includes many tangible costs. The decision to use the Balducci data was made after an extensive review of other studies that have been published on 
downtime costs. Even though these other studies were not ultimately used, it is important to look at their conclusions to make sure that the conclusions of this analysis appear to be reasonable. The results of these studies can also be used to make extrapolations beyond the limits of chosen data, such as assessing the costs of longer power outages.

The Balducci study looked at 17 data sets before deciding that the data set it used was the best. ${ }^{11}$ Several of the other data sets they examined were obtained more recently than the data they ultimately used, and thus would likely better capture the impact of technological changes that have occurred in the economy since 1996. Some of these studies were not used because they were conducted in countries with economies that are very different from the U.S., like Greece, Nepal, and Mexico. Other studies were not used because they only looked at one sector of the economy, while others looked at all sectors but did not examine the important differences in outage costs that exist among subsectors of the commercial and industrial sectors.

The conclusion that the Balducci data set is the best available is also supported by a 2001 literature review compiled by researchers at LBNL. ${ }^{12}$ In their review of 14 data sets that have been published on the topic of outage costs, the data used by Balducci is the most recent and the most comprehensive. As highlighted in Table 3, the literature review also presents a quantitative assessment of the results of these data sets, comparing the figures that each data set found for outage costs. The data sets used by Balducci, et al., are those labeled Saskatchewan 1991 and Saskatchewan 1995. While there are large differences in the data among some of the studies, data from this paper is in the middle of the overall range and is comparable to that produced by many of the other studies, lending additional confidence to preliminary conclusions.

Table 3: LBNL Summary of Published Reports on Outage Costs ${ }^{13}$

\begin{tabular}{|c|c|c|c|c|c|c|c|c|c|c|c|}
\hline \multicolumn{12}{|c|}{ Outage Duration } \\
\hline Study & $\begin{array}{c}\text { Momen- } \\
\text { tary }\end{array}$ & $\begin{array}{l}<1 \\
\text { min }\end{array}$ & $1 \mathrm{~min}$ & $\begin{array}{c}15 \\
\min \end{array}$ & $\begin{array}{c}20 \\
\text { min }\end{array}$ & $1 \mathrm{hr}$ & $2 \mathrm{hr}$ & $4 \mathrm{hr}$ & $8 \mathrm{hr}$ & $24 \mathrm{hr}$ & Notes \\
\hline \multicolumn{12}{|c|}{ \$/kW annual peak demand } \\
\hline $\begin{array}{l}\text { Saskatchewan } \\
1988\end{array}$ & & & 0.394 & & 3.070 & 8.844 & & 32.390 & 85.846 & & Commercial \\
\hline $\begin{array}{l}\text { Saskatchewan } \\
1988\end{array}$ & & & 1.681 & & 4.000 & 9.395 & & 26.023 & 57.715 & & Small industrial \\
\hline $\begin{array}{l}\text { Saskatchewan } \\
1988\end{array}$ & & & 1.039 & & 1.560 & 2.301 & & 4.104 & 8.522 & & Large industrial \\
\hline $\begin{array}{l}\text { Saskatchewan } \\
1991\end{array}$ & 0.281 & & 1.973 & & 5.837 & 15.769 & & 79.451 & 127.669 & 153.767 & Commercial \\
\hline $\begin{array}{l}\text { Saskatchewan } \\
1991\end{array}$ & & & & & & & 33.079 & & & & Commercial \\
\hline $\begin{array}{l}\text { Saskatchewan } \\
19981\end{array}$ & 0.946 & & 2.259 & & 3.233 & 6.831 & & 24.921 & 46.118 & 73.409 & Industrial \\
\hline $\begin{array}{l}\text { Saskatchewan } \\
19981\end{array}$ & & & & & & & 12.121 & & & & Industrial \\
\hline $\begin{array}{l}\text { Nordic Study } \\
1992-93\end{array}$ & 0.653 & & 0.762 & 1.851 & & 9.254 & & & 61.515 & & $\begin{array}{l}\text { Denmark, winter } \\
\text { weekday. } \\
\text { Commercial. }\end{array}$ \\
\hline $\begin{array}{l}\text { Nordic Study } \\
1992-93\end{array}$ & 2.722 & & 2.940 & 6.859 & & 17.856 & & & 97.335 & & $\begin{array}{l}\text { Finland, winter } \\
\text { weekday. } \\
\text { Commercial. }\end{array}$ \\
\hline $\begin{array}{l}\text { Nordic Study } \\
1992-93\end{array}$ & 5.008 & & 5.988 & 7.295 & & 22.864 & & & 104.304 & & $\begin{array}{l}\text { Iceland, winter } \\
\text { weekday. } \\
\text { Commercial. }\end{array}$ \\
\hline $\begin{array}{l}\text { Nordic Study } \\
1992-93\end{array}$ & 0.109 & & 0.109 & 0.762 & & 4.464 & & & 45.510 & & $\begin{array}{l}\text { Denmark, } \\
\text { planned outage, } \\
\text { winter weekday. } \\
\text { Commercial. }\end{array}$ \\
\hline $\begin{array}{l}\text { Nordic Study } \\
1992-93\end{array}$ & 1.415 & & 1.524 & 3.049 & & 11.432 & & & 64.999 & & $\begin{array}{l}\text { Finland, planned } \\
\text { outage, winter } \\
\text { weekday. } \\
\text { Commercial. }\end{array}$ \\
\hline
\end{tabular}




\begin{tabular}{|c|c|c|c|c|c|c|c|c|c|c|c|}
\hline \multicolumn{12}{|c|}{ Outage Duration } \\
\hline Study & $\begin{array}{c}\text { Momen- } \\
\text { tary }\end{array}$ & $\begin{array}{l}<1 \\
\min \end{array}$ & $1 \mathrm{~min}$ & $\begin{array}{c}15 \\
\min \end{array}$ & $\begin{array}{c}20 \\
\min \end{array}$ & $1 \mathrm{hr}$ & $2 \mathrm{hr}$ & $4 \mathrm{hr}$ & $8 \mathrm{hr}$ & $24 \mathrm{hr}$ & Notes \\
\hline \multicolumn{12}{|c|}{ \$/kW annual peak demand } \\
\hline & & & & & & & & & & & \\
\hline $\begin{array}{l}\text { Nordic Study } \\
1992-93\end{array}$ & 0.109 & & 0.327 & 1.633 & & 15.460 & & & 88.408 & & $\begin{array}{l}\text { Iceland, planned } \\
\text { outage, winter } \\
\text { weekday. } \\
\text { Commercial. }\end{array}$ \\
\hline $\begin{array}{l}\text { Nordic Study } \\
1992-93\end{array}$ & 1.524 & & 4.355 & 13.065 & & 24.062 & & & 77.847 & & $\begin{array}{l}\text { Denmark, } \\
\text { unexpected } \\
\text { (winter weekday). } \\
\text { Industrial. }\end{array}$ \\
\hline $\begin{array}{l}\text { Nordic Study } \\
1992-93\end{array}$ & 2.940 & & 4.137 & 7.948 & & 15.787 & & & 83.290 & & $\begin{array}{l}\text { Finland, } \\
\text { unexpected } \\
\text { (winter weekday). } \\
\text { Industrial. }\end{array}$ \\
\hline $\begin{array}{l}\text { Nordic Study } \\
1992-93\end{array}$ & 0.218 & & 0.218 & 9.254 & & 13.610 & & & 66.088 & & $\begin{array}{l}\text { Iceland, } \\
\text { unexpected } \\
\text { (winter weekday). } \\
\text { Industrial. }\end{array}$ \\
\hline $\begin{array}{l}\text { Nordic Study } \\
1992-93\end{array}$ & 0.327 & & 0.980 & 1.960 & & 5.553 & & & 38.651 & & $\begin{array}{l}\text { Denmark, } \\
\text { planned outage } \\
\text { (winter weekday). } \\
\text { Industrial. }\end{array}$ \\
\hline $\begin{array}{l}\text { Nordic Study } \\
1992-93\end{array}$ & 0.762 & & 1.524 & 2.613 & & 6.533 & & & 49.430 & & $\begin{array}{l}\text { Finland, planned } \\
\text { outage (winter } \\
\text { weekday). } \\
\text { Industrial. } \\
\end{array}$ \\
\hline $\begin{array}{l}\text { Nordic Study } \\
1992-93\end{array}$ & 0.109 & & 0.109 & 0.653 & & 3.702 & & & 33.969 & & $\begin{array}{l}\text { Iceland, planned } \\
\text { outage (winter } \\
\text { weekday). } \\
\text { Industrial. }\end{array}$ \\
\hline $\begin{array}{l}\text { Saskatchewan } \\
1995\end{array}$ & 1.312 & & & & 2.584 & 5.720 & & 16.905 & & & $\begin{array}{l}\text { Government, } \\
\text { institutional and } \\
\text { office sector }\end{array}$ \\
\hline
\end{tabular}

As seen in Figure 4 below, a 2003 outage cost study by LBNL includes data from more recent surveys. ${ }^{14}$ This study compiled data from 24 surveys that were administered by U.S. utilities from 1989 to 2002. Unfortunately, because these surveys are the property of the utilities and contain confidential information, the data from individual studies were not made public. Instead, the data from the 24 studies was combined into one data set, which makes analysis of data from individual surveys impossible.

The data set produced by the LBNL study differs from the Balducci data set in several ways. For one, this data set examines interruption costs for outages up to 12 hours in duration, instead of four hours. However, because only 3 of the 24 studies in the combined data set looked at outage costs for time periods beyond 4 hours, it may be inaccurate to estimate costs for longer outages based on this data. In fact, the combined data set shows total costs for longer outages to be lower than the total cost for shorter outages, a result that does not make intuitive sense and therefore raises questions about the accuracy of those three studies. This anomaly is illustrated in Figure 4. In addition, the LBNL data set only covers several general sectors of the economy, in contrast to the comprehensive and detailed subsector data available from the Balducci study.

However, useful information can still be obtained from the LBNL study. For one, the results of this study lend additional credence to the results of this paper's analysis. E.g., the LBNL study found that outage costs to large commercial and industrial businesses increase nonlinearly as the outage duration increases from one to eight hours. In addition, the study's results for costs for the typical establishment in the manufacturing, retail, office, and service sectors are comparable to the results of this paper's analysis. 


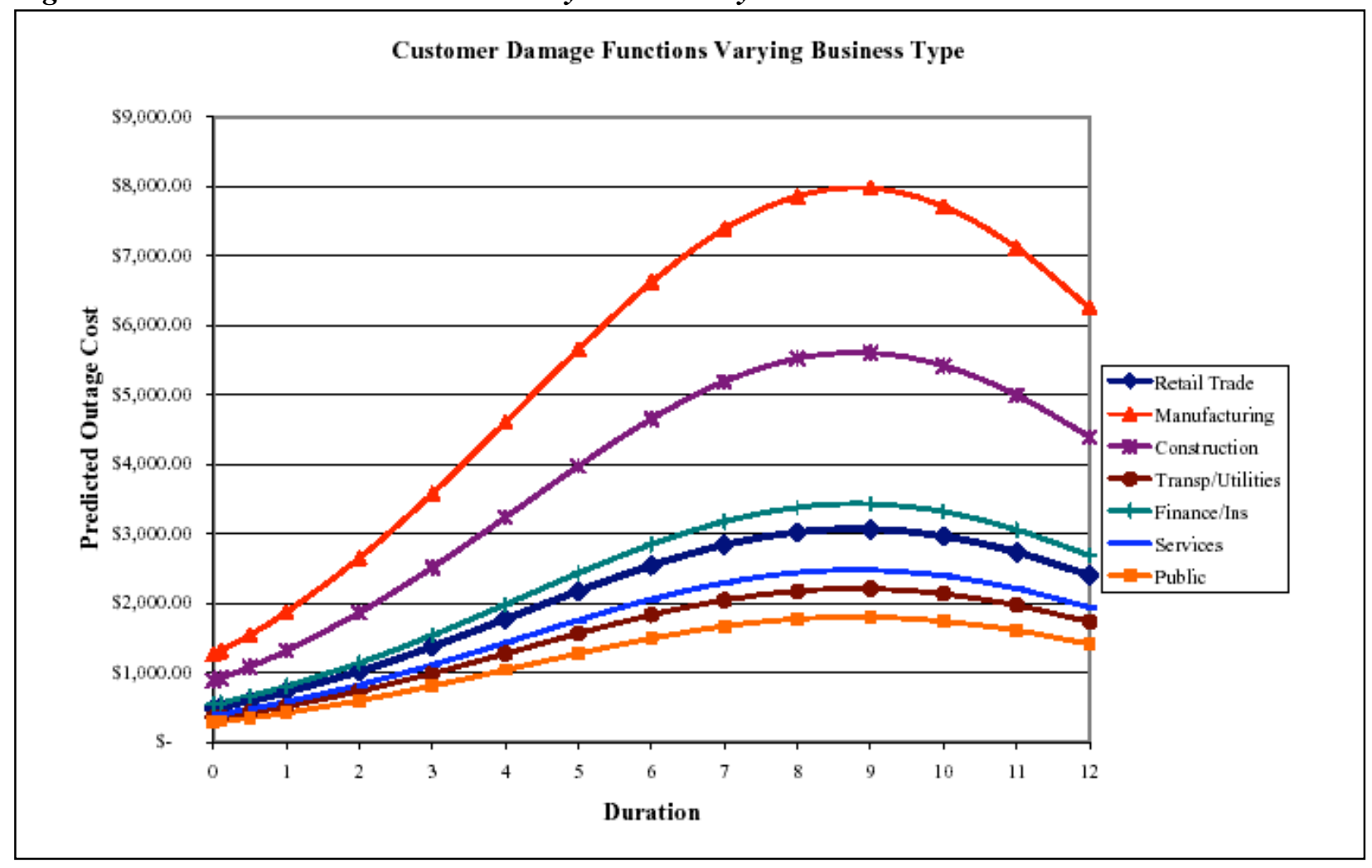

The results of other studies also support the conclusion that the results of this paper's analysis are reasonable. A 2006 LBNL study estimated that, in an average year in the U.S., sustained power interruptions cost the U.S. economy $\$ 26.3$ billion. ${ }^{15}$ This paper's calculation of $\$ 19.2$ billion in annual costs from sustained outages, which is discussed in the Appendix, thus appears to be reasonable. Furthermore, the LBNL study's breakdown of costs for the commercial, industrial, and residential sectors is similar to this paper's findings. The LBNL found that the commercial sector accounts for $72 \%$ of the total cost of power outages, while the industrial sector accounts for $26 \%$ and the residential sector accounts for 2\%. As Figure 10 illustrates in the Appendix, our study produced similar figures, with the commercial sector contributing $60 \%$ of total costs, the industrial sector $37 \%$, and the residential sector $3 \%$.

\section{Comparison of Results to Available Market Data}

A potential hazard in any theoretical study is that its results don't reflect "real world" applications. In an effort to compare theoretical calculations of business downtime costs with actual market data, the costs were reviewed by representatives of two sets of well-defined, geographically-limited markets:

1. California's refrigerated warehouse market; and

2. Michigan's food retail market.

\section{California Refrigerated Warehouse Market}

As noted above, the refrigerated warehouse market was the one subsector that stood out as an exception to the generalization that typical establishments in industrial subsectors suffered greater financial losses from downtime than typical establishments in commercial subsectors. To learn more about the market, data was gathered from the International Association of Refrigerated Warehouse (IARW) website. Refrigerated warehouse space in the U.S. currently exceeds 2.35 billion cubic feet spread over 827 
facilities, according to IARW. To narrow down the sample size, California was chosen as the state to assess further because it leads the nation in refrigerated warehouses with 309,960,000 cubic feet.

To calculate average refrigerated warehouse downtime costs, CBECS data from 1999 on the energy use of refrigerated warehouses was adjusted to 2003 based on the number of refrigerated warehouses in 2003. According to 2003 CBECS data, there are 15,100 refrigerated warehouses, each with an average square footage of 63,776 . Each building uses $1,250,000 \mathrm{kWh}$, or $19.6 \mathrm{kWh} / \mathrm{sq} \mathrm{ft}$, for a total sector usage of 18.9 billion $\mathrm{kWh}$. Using the data from CBECS and the Balducci study, the data in Table 4 were calculated to be the business downtime costs for the average refrigerated warehouse:

Table 4: Average Refrigerated Warehouse Business Downtime Costs as a Function of Power Outage Duration

\begin{tabular}{|l|l|}
\hline Time after Power Outage & "Average" Refrigerated Warehouse Business Downtime Costs \\
\hline 20 minutes & $\$ 7,710$ \\
\hline 1 hour & $\$ 23,100$ \\
\hline 4 hours & $\$ 120,000$ \\
\hline
\end{tabular}

Data on 20 actual refrigerated warehouses (anonymously numbered below) based in California were gathered from the IARW website. Cubic feet of refrigerated warehouse space was converted to area by applying 30 feet as an average refrigerated warehouse height. By applying the $19.6 \mathrm{kWh} / \mathrm{sq}$. $\mathrm{ft}$. factor derived from CBECS data, and the Balducci downtime cost factor data, calculations were made to estimate the costs of downtime for the California refrigerated warehouses at 20,60, and 240-minute points in time after power outage. The results are summarized in Table 5.

Table 5: Cumulative Downtime Costs of 20 California Refrigerated Warehouses as a Function of Power Outage Duration

\begin{tabular}{|l|r|r|r|r|r|r|}
\hline $\begin{array}{c}\text { California } \\
\text { Refrigerated } \\
\text { Warehouse }\end{array}$ & $\begin{array}{c}\text { Area } \\
\text { (sq. ft.) }\end{array}$ & $\begin{array}{c}\text { Avg. Energy } \\
\text { Intensity } \\
\text { (kWh/sq. ft.) }\end{array}$ & $\begin{array}{c}\text { Annual } \\
\text { Energy Use } \\
\text { (kWh/yr) }\end{array}$ & $\begin{array}{c}\text { Downtime } \\
\text { Cost } \\
\text { (20 Mins.) }\end{array}$ & $\begin{array}{c}\text { Downtime } \\
\text { Cost } \\
\text { (60 Mins) }\end{array}$ & $\begin{array}{c}\text { Downtime } \\
\text { Cost } \\
(\mathbf{2 4 0} \text { Mins) }\end{array}$ \\
\hline 1 & $50,242.5$ & 19.6 & 984,753 & $\mathbf{\$ 6 , 0 0 0}$ & $\mathbf{\$ 1 8 , 0 0 0}$ & $\mathbf{\$ 9 3 , 6 0 0}$ \\
\hline 2 & $12,000.0$ & 19.6 & 235,200 & $\mathbf{\$ 1 , 4 3 0}$ & $\mathbf{\$ 4 , 2 9 0}$ & $\mathbf{\$ 2 2 , 4 0 0}$ \\
\hline 3 & $90,928.3$ & 19.6 & $1,782,195$ & $\mathbf{\$ 1 0 , 9 0 0}$ & $\mathbf{\$ 3 2 , 5 0 0}$ & $\mathbf{\$ 1 7 0 , 0 0 0}$ \\
\hline 4 & $63,333.3$ & 19.6 & $1,241,333$ & $\mathbf{\$ 7 , 5 5 0}$ & $\mathbf{\$ 2 2 , 7 0 0}$ & $\mathbf{\$ 1 1 8 , 0 0}$ \\
\hline 5 & $70,266.7$ & 19.6 & $1,377,227$ & $\mathbf{\$ 8 , 3 8 0}$ & $\mathbf{\$ 2 5 , 1 0 0}$ & $\mathbf{\$ 1 3 1 , 0 0 0}$ \\
\hline 6 & $115,000.0$ & 19.6 & $2,254,000$ & $\mathbf{\$ 1 3 , 7 0 0}$ & $\mathbf{\$ 4 1 , 1 0 0}$ & $\mathbf{\$ 2 1 4 , 0 0 0}$ \\
\hline 7 & $100,000.0$ & 19.6 & $1,960,000$ & $\mathbf{\$ 1 1 , 9 0 0}$ & $\mathbf{\$ 3 5 , 8 0 0}$ & $\mathbf{\$ 1 8 6 , 0 0 0}$ \\
\hline 8 & $48,333.3$ & 19.6 & 947,333 & $\mathbf{\$ 5 , 7 6 0}$ & $\mathbf{\$ 1 7 , 3 0 0}$ & $\mathbf{\$ 9 0 , 0 0 0}$ \\
\hline 9 & $18,274.2$ & 19.6 & 358,174 & $\mathbf{\$ 2 , 1 8 0}$ & $\mathbf{\$ 6 , 5 4 0}$ & $\mathbf{\$ 3 4 , 0 0 0}$ \\
\hline 10 & $17,300.0$ & 19.6 & 339,080 & $\mathbf{\$ 2 , 0 6 0}$ & $\mathbf{\$ 6 , 1 9 0}$ & $\mathbf{\$ 3 2 , 2 0 0}$ \\
\hline 11 & $46,666.7$ & 19.6 & 914,667 & $\mathbf{\$ 5 , 5 7 0}$ & $\mathbf{\$ 1 6 , 7 0 0}$ & $\mathbf{\$ 8 6 , 9 0 0}$ \\
\hline 12 & $53,868.2$ & 19.6 & $1,055,817$ & $\mathbf{\$ 6 , 4 2 0}$ & $\mathbf{\$ 1 9 , 3 0 0}$ & $\mathbf{\$ 1 0 0 , 0 0 0}$ \\
\hline 13 & $146,666.7$ & 19.6 & $2,874,667$ & $\mathbf{\$ 1 7 , 5 0 0}$ & $\mathbf{\$ 5 2 , 5 0 0}$ & $\mathbf{\$ 2 7 3 , 0 0 0}$ \\
\hline 14 & $25,751.9$ & 19.6 & 504,737 & $\mathbf{\$ 3 , 0 7 0}$ & $\mathbf{\$ 9 , 2 1 0}$ & $\mathbf{\$ 4 8 , 0 0 0}$ \\
\hline 15 & $254,666.7$ & 19.6 & $4,991,467$ & $\mathbf{\$ 3 0 , 4 0 0}$ & $\mathbf{\$ 9 1 , 1 0 0}$ & $\mathbf{\$ 4 7 4 , 0 0 0}$ \\
\hline 16 & $32,459.3$ & 19.6 & 636,202 & $\mathbf{\$ 3 , 8 7 0}$ & $\mathbf{\$ 1 1 , 6 0 0}$ & $\mathbf{\$ 6 0 , 5 0 0}$ \\
\hline 17 & $18,000.0$ & 19.6 & 352,800 & $\mathbf{\$ 2 , 1 5 0}$ & $\mathbf{\$ 6 , 4 4 0}$ & $\mathbf{\$ 3 3 , 5 0 0}$ \\
\hline 18 & $369,303.7$ & 19.6 & $7,238,353$ & $\mathbf{\$ 4 4 , 0 0 0}$ & $\mathbf{\$ 1 3 2 , 0 0 0}$ & $\mathbf{\$ 6 8 8 , 0 0 0}$ \\
\hline 19 & $211,770.9$ & 19.6 & $4,150,710$ & $\mathbf{\$ 2 5 , 3 0 0}$ & $\mathbf{\$ 7 5 , 8 0 0}$ & $\mathbf{\$ 3 9 5 , 0 0 0}$ \\
\hline 20 & $15,303.0$ & 19.6 & 299,939 & $\mathbf{\$ 1 , 8 3 0}$ & $\mathbf{\$ 5 , 4 8 0}$ & $\mathbf{\$ 2 8 , 5 0 0}$ \\
\hline
\end{tabular}


To validate these results, they were sent out for review by email to all 20 California IARW members, with zero email responses. Upon reaching five refrigerated warehouse contacts willing to talk by phone, with the assurance of anonymity, it became apparent that the theoretical costs of business downtime in this report were extremely high and not representative of the refrigerated warehouse industry. For example:

- In terms of total downtime costs, refrigerated warehouse representatives noted that the calculated costs were extremely high; not representative of the refrigerated warehouse industry. One refrigerated warehouse owner noted that he had lost power 3 times over the last 35 years with no resultant inventory or revenue losses.

- Electronic data loss would be minimal, primarily due to UPS backup systems for computers.

- The only potential revenue loss would be from turning customers away from bays which would lose cooling if doors were opened; one refrigerated warehouse owner noted that those customers would simply come back when power was restored.

- Idle labor is perhaps the only downtime loss that refrigerated warehouse industry would be concerned about, but these costs would not be significant.

- In regards to damaged inventory, refrigerated warehouse frozen inventory would be safe for 2-3 days; in this time period, backup diesel generators could be secured. One refrigerated warehouse owner noted that he lost power for one week in 2000 , but he was able to rent a diesel genset for backup power within 15 hours of the power outage.

- There would be minimal costs associated with turning computers and chillers back on for repair and ramp-up; on-hand staff could handle.

Based on these summary responses from the limited California refrigerated warehouse contacts, the downtime costs calculated in this report show very little resemblance to the actual costs incurred from power outage in the refrigerated warehouse industry. Refrigerated warehouse representatives reported that their business downtime costs were minimal and perhaps constrained to diesel fuel and equipment rental fees - in sharp contrast to this paper's calculated cost of $\$ 687,969$ over 4 hours for the largest refrigerated warehouse in California in this paper's data set.

\section{Michigan Food Retail Market}

This paper's downtime cost calculations for food sales were then compared to data from Michigan's food retail market from a post-2003 Blackout survey by the Electricity Consumers Resource Council $(\mathrm{ELCON})^{16}$. On August 14, 2003, North America experienced the largest blackout in history, affecting eight states in the Midwest and Northeast, and parts of Canada. At its peak, over 50 million people were without power, and businesses may have lost at least $\$ 6$ Billion in direct costs. ${ }^{17}$ The ELCON report uses data gathered from the Associated Food Dealers of Michigan, an organization representing Michigan's food industry, ${ }^{18}$ which reports that its 3,000 members lost approximately $\$ 50$ million from the 2003 Blackout, or approximately $\$ 18,000$ /establishment. However, to compare this cost with our results, one must know the average amount of time that these stores were without power as a result of the blackout.

To find the most representative downtime point, data from an ICF report can be used to "assume that the initial outage of $61,800 \mathrm{MW}$ lasted for 4 hours and then half of that was restored...." 19 Thus, for purposes of this paper, the 4-hour business downtime cost for Michigan's food and beverage industry was chosen. Our data predicted the costs of a four-hour outage would be $\$ 26,234$ for the typical grocery store establishment - within 30\% of the actual cost reported by the Associated Food Dealers of Michigan. 


\section{CONCLUSIONS}

\section{A. Downtime Cost Components}

As seen in the refrigerated warehouse comparison of calculated costs versus actual, downtime cost components vary radically from subsector to subsector, market to market. For example, in the refrigerated warehouse industry, the only important downtime cost components were idle labor and backup genset rental costs. Equipment damage, data loss, inventory damage, lost revenue and productivity, late fees and other tangible and intangible costs simply did not apply to this market. The "common sense" assumption that inventory loss would be a major downtime cost component was totally inaccurate, for example, illustrating the importance of understanding a market and its idiosyncratic characteristics before estimating its costs of business downtime.

The refrigerated warehouse example also serves to show the variability in power reliability and quality needs in a business type. The industries chosen for Table 1, cited previously in this paper, were all dependent on high levels of power reliability and quality, skewing the downtime costs. If the refrigerated warehouse industry had been chosen for this table of outage costs, the overall impression would have been radically different. On the other hand, downtime costs calculated in this paper for food sales were much more accurate and representative of the industry; surveys could be utilized to portray a more accurate accounting of its downtime cost components.

\section{B. Business Type}

Downtime cost components are logically linked to business type. This paper's findings support the conclusion that total downtime costs are highly dependent on the type of business experiencing the power outage and on the duration of the blackout. For some businesses and industries, it was found that the most costly disruptions and damages occur in the initial minutes of an outage, while other sectors of the economy can endure short outages with minimal costs but are highly vulnerable to prolonged outages. Offices and the health care sector are highly vulnerable to disruptions and damage in the initial minutes of an outage, with more than half of the costs of a four-hour outage occurring during the initial 20 minutes. Many industries are also highly vulnerable to short-term outages, as products and equipment can be irreversibly damaged if a production process is interrupted due to a power outage. In contrast, grocery stores, refrigerated warehouses, and restaurants can endure short outages with minimal costs, but they face large expenses if an outage continues for enough time that refrigerated and frozen food begins to spoil and must be discarded.

Figure 5 illustrates differences in how two business types - paper product manufacturers and food salesvary in response to outages of different durations. While the two subsectors face comparable costs for a 20 minute outage, downtime costs for the food sales business rapidly escalate for longer outages. In contrast, the majority of the outage costs for the paper industry occur during the initial 20 minutes of an outage, and costs are only slightly higher for longer outages. 
Figure 5: Cumulative Business Downtime Costs as a Function of Power Outage Duration in Two Subsectors

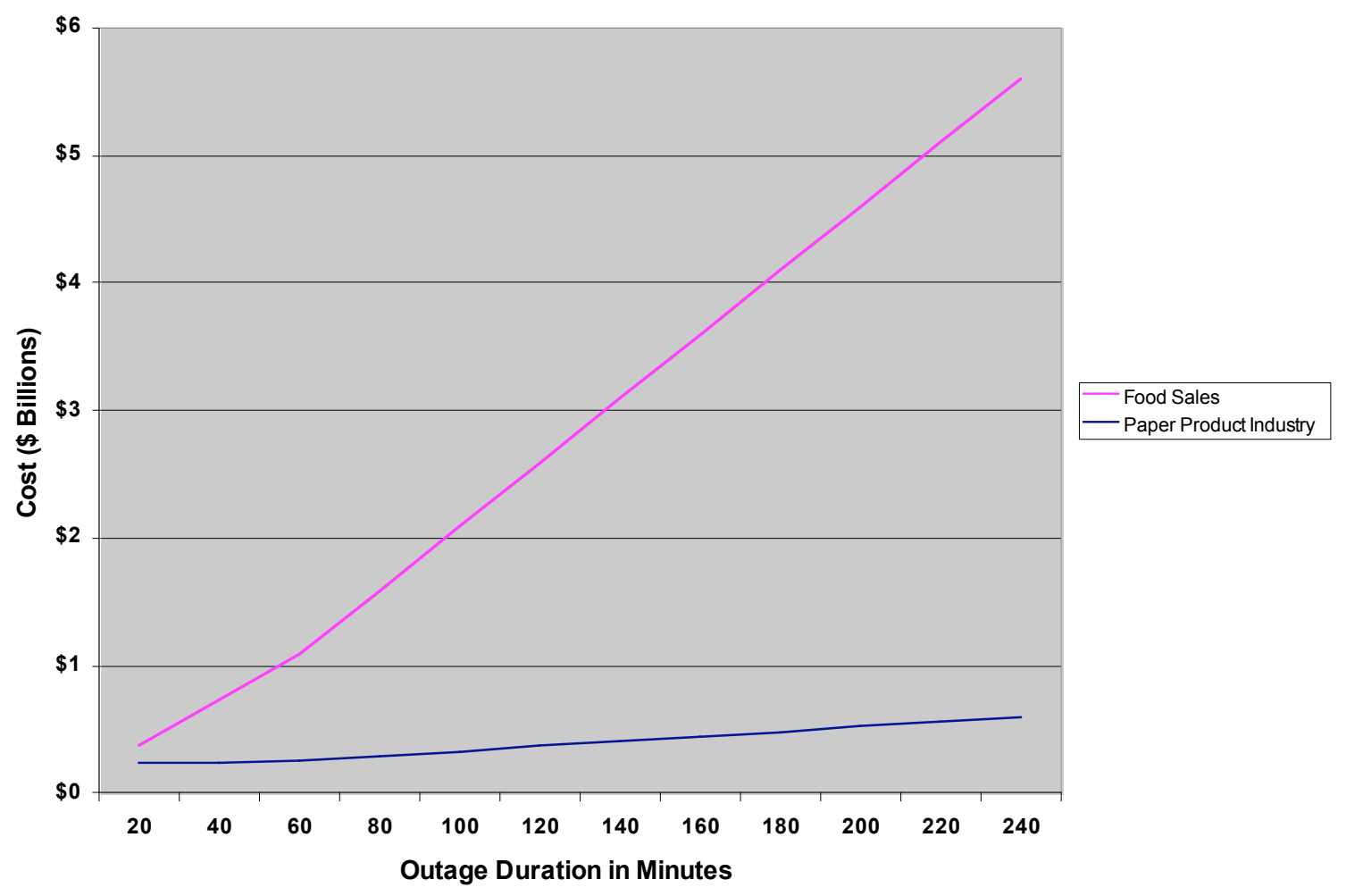

\section{Power Outage Duration}

Table 1 presented "average cost of downtime" for five industries, but did not take into account the way in which businesses lose different amounts of money as a function of outage duration. This paper shows a definite time factor in calculating business downtime costs.

Figure 6 presents a breakdown of outage costs over time for the commercial subsectors. As one can see, at 20 minutes duration, almost all commercial subsectors have comparable downtime costs. However, as an outage persists and food spoilage sets in, costs for restaurants (food service) and grocery stores (food sales) increase faster than for other sectors. 
Figure 6: Cumulative Downtime Costs as a Function of Power Outage Duration in Select Subsectors

Commercial Subsector Power Outage Costs

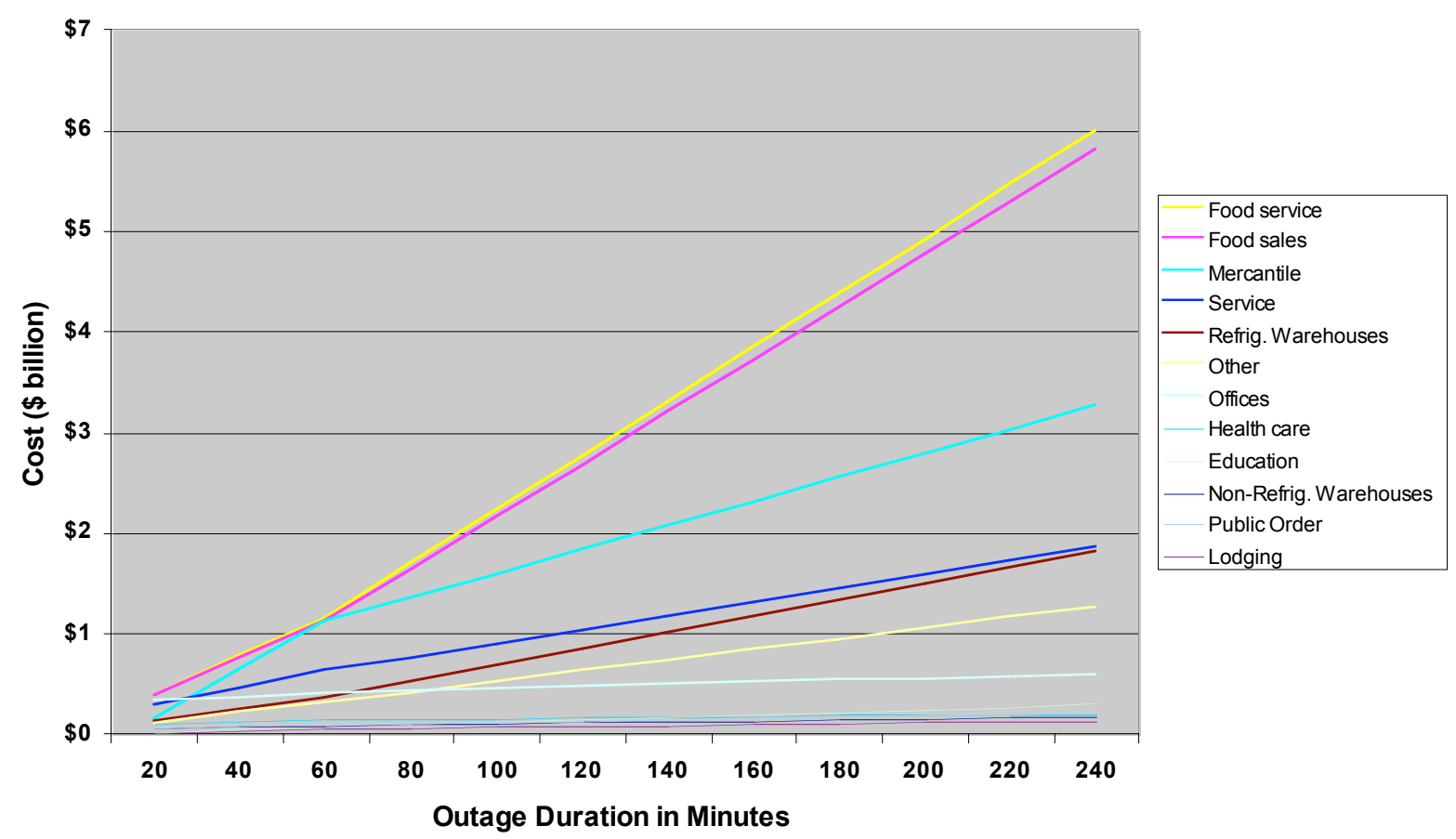

The next two charts, Figures 7 and 8, provide another way to illustrate these changes in the distribution of costs for commercial subsectors over the duration of a blackout. One can see that the share of costs experienced by food service and sales grows until it accounts for the majority of costs after four hours of outage duration. These charts also illustrate that offices incur large costs during the initial minutes of a blackout, but subsequent losses are much smaller. Presumably, this is because of the high cost of data loss and damage to computer equipment that occurs during the initial moments of a blackout; more data collection and analysis would be needed to confirm this interpretation.

Figures 7 and 8: Economy-wide Costs after 20 Minutes and 4 Hours in Commercial Subsectors
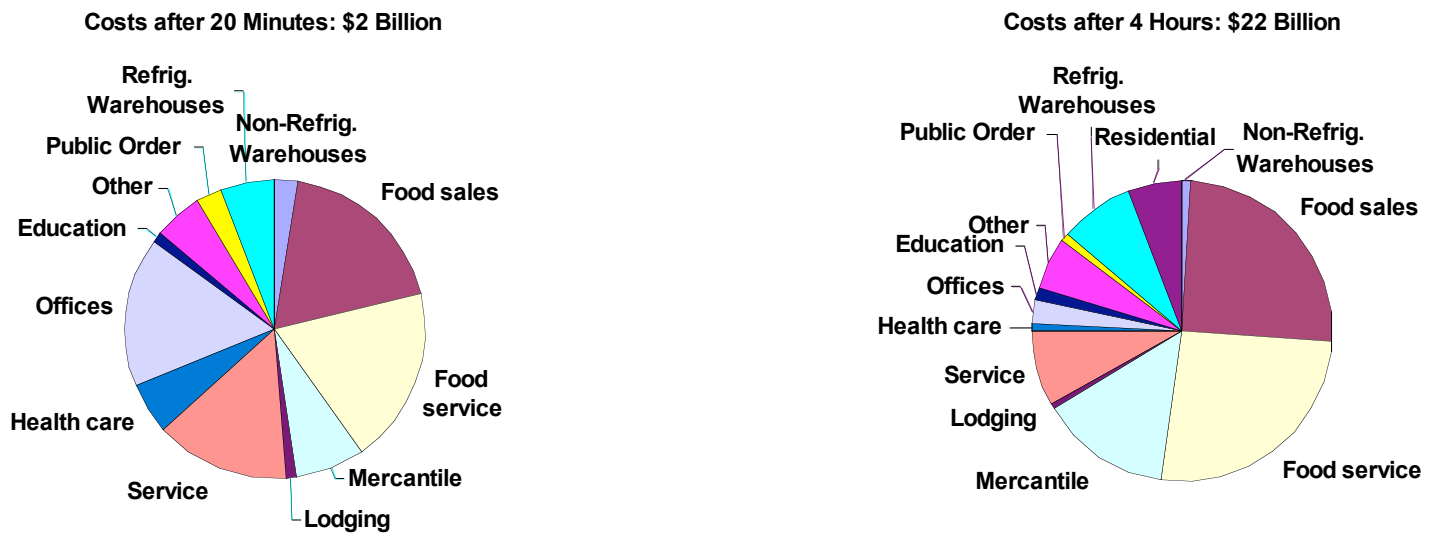
Similar trends can be seen among industrial subsectors. In general, most industries have relatively flat downtime cost lines, indicating that a large share of the total costs is incurred during the initial minutes of an outage. This makes intuitive sense, as significant damage can result when a factory is unable to finish an industrial process because of a power outage. For example, if the power needed to continue heating or stirring a molten substance is suddenly lost due to an outage, the material can congeal in its container and ruin both the product and the equipment in a matter of minutes. The transportation equipment industry, i.e. automobile factories, appears to be the exception to this rule in that they experience increasing marginal costs over time. This may be a result of the fact that short outages can be compensated for by simply running the assembly line a little longer, but longer interruptions can cause serious disruptions in product supply that cannot be made up.

Figure 9: Cumulative Industrial Subsector Power Outage Costs

Industrial Subsector Power Outage Costs

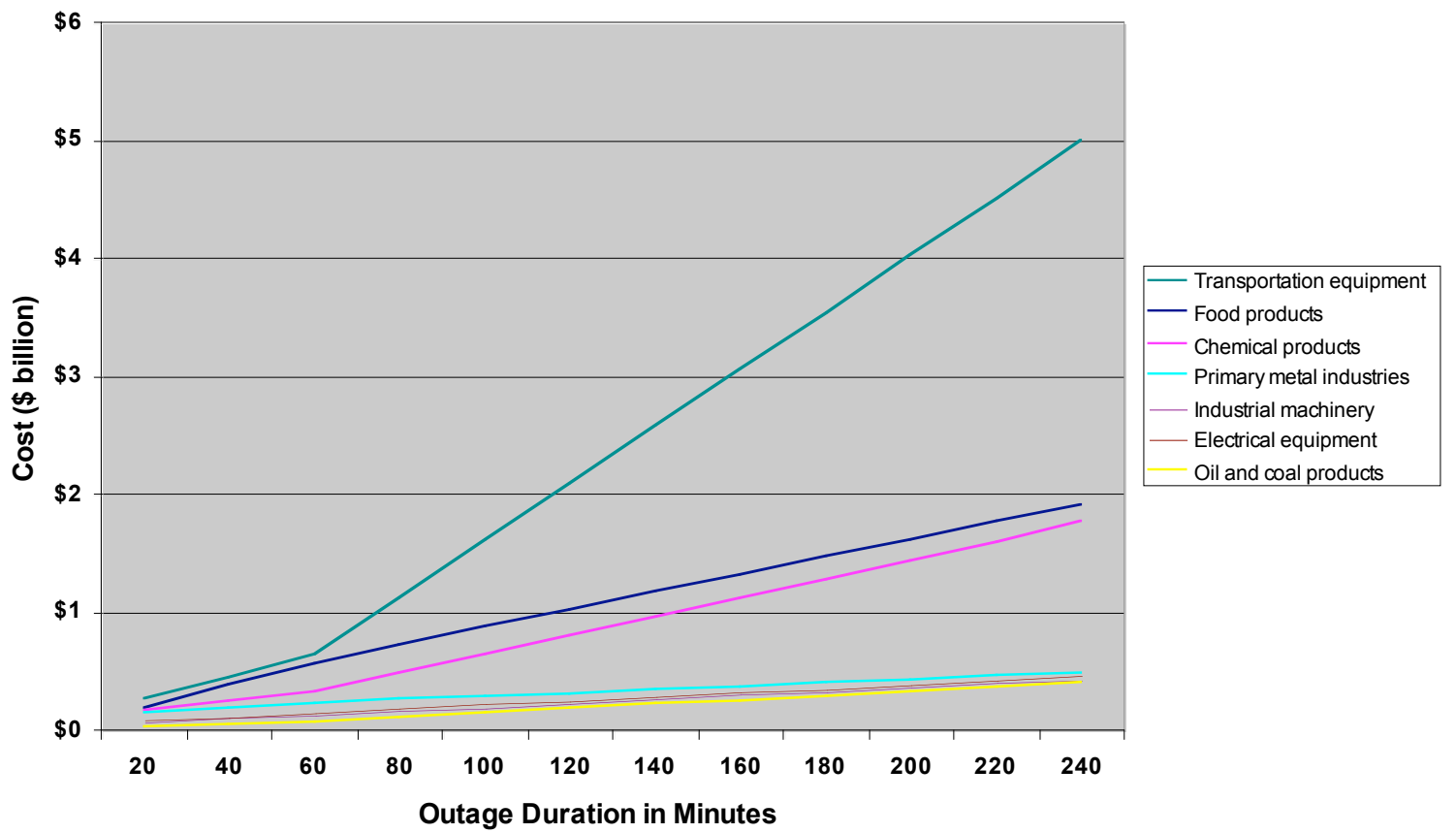

\section{Implications for Onsite Energy for Greater Business Continuity}

Most small businesses underestimate the loss of profit that comes with a disaster related to power outage and business downtime, according to Robert Hartwig, Chief Economist for the Insurance Information Institute. About 50 percent of disaster damages are business claims, including those for the interruption of business, according to Hartwig, who notes that "the No. 1 killer of businesses is not the loss of the property, because they get enough coverage to rebuild. It's the loss of profits while the business is closed, because they operate on such a thin margin." ${ }^{20}$

With a growing trend in the business world of "business continuity planning" that would ensure financial continuity, customer satisfaction, and productivity despite a catastrophe, business owners in select subsectors that suffer most from business downtime could realize substantial financial gains from reliable power achievable through onsite power. 
A 2004 report by business consulting firms ${ }^{21}$ summarized the findings of an industry survey conducted of 142 companies during the months immediately following the 2003 blackout. Question \#6 on this survey was:

"As a consequence of The Blackout, do you think your firm will be more likely to consider investments in alternate energy generation, storage and/or distribution systems?"

In response to this question, $38.7 \%$ of businesses surveyed said they'd be "somewhat" or "very likely" to invest in alternate energy systems. With a greater understanding of the current costs and cost components of downtime, the variability in downtime costs due to business type, and the change in downtime costs over time, business owners may be better able to calculate the true value of reliable, high quality, power from onsite energy. 


\section{APPENDIX}

To provide a glimpse of the impact of power outages to the American economy, one output of our analysis was the aggregate cost of power outages for the three major sectors of the economy, as summarized in Tables 6-9 and Figures 10-12. To calculate this cost, data was obtained on the average duration and average frequency of real power outages in the United States. The average customer on a power system in the United States experiences 1.2 sustained outages (lasting more than a few seconds) per year, and the average sustained outage lasts for 106 minutes. ${ }^{22}$ The average customer also experiences 4.3 momentary power interruptions per year, but because comprehensive data on the cost of momentary power interruptions is not available these interruptions were not included in the calculation. The cost of a 106 minute outage was then calculated using the Balducci data, and the result was multiplied by 1.2 to reflect the average annual cost of power outages for each sector.

As shown in Fig. 10, the commercial and industrial sectors account for the majority of costs caused by power outages.

Figure 10: Average Annual Cost of Sustained Outages, by Sector

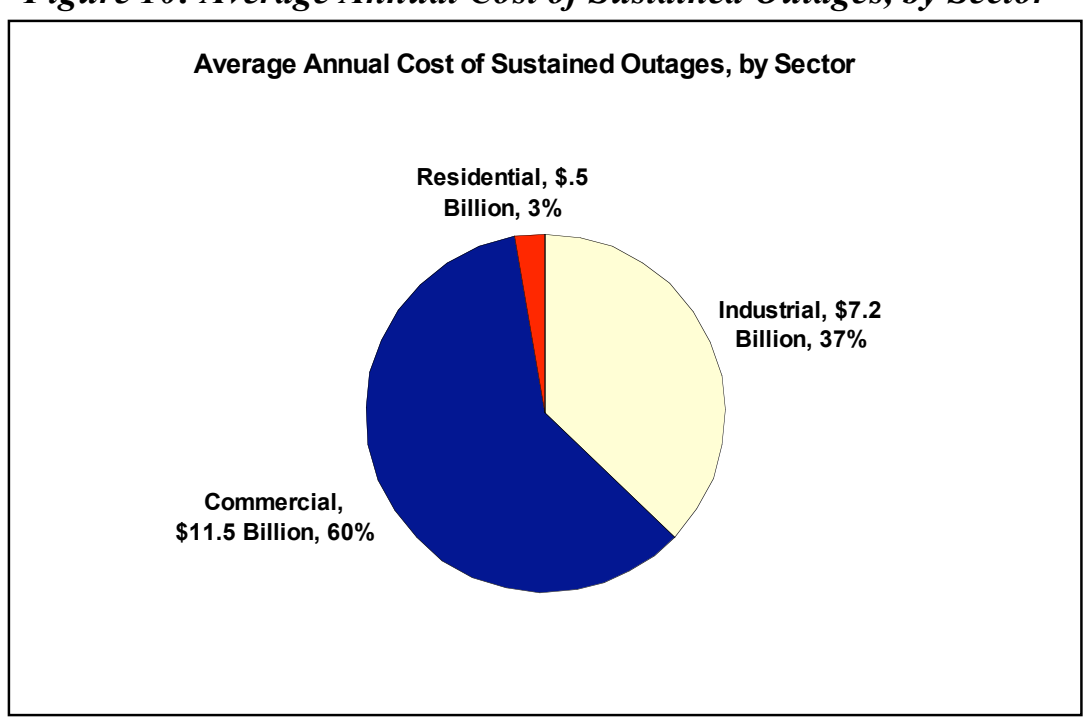

\section{Sector Results}

Table 6: Average Sustained Outage Costs for Different Sectors of the Economy, Based on 1.2 Annual Outages of 106 Minutes Each

\begin{tabular}{|l|r|}
\hline \multicolumn{1}{|c|}{ Sector } & Average Annual Outage Cost \\
\hline Industrial & $\$ 7,190,000,000$ \\
\hline Commercial & $\$ 11,500,000,000$ \\
\hline Residential & $\$ 529,000,000$ \\
\hline Total & $\$ 19,300,000,000$ \\
\hline
\end{tabular}

Table 7: Cost of Economy-wide Outages of Varying Durations for Different Sectors

\begin{tabular}{|l|r|r|r|}
\hline \multicolumn{1}{|c|}{ Sector } & 20 Minutes & \multicolumn{1}{c|}{ 1 Hour } & \multicolumn{1}{c|}{ 4 Hours } \\
\hline Industrial & $\$ 1,600,000,000$ & $\$ 3,170,000,000$ & $\$ 14,200,000,000$ \\
\hline Commercial & $\$ 2,000,000,000$ & $\$ 5,510,000,000$ & $\$ 21,600,000,000$ \\
\hline Residential & $\$ 25,000,000$ & $\$ 125,000,000$ & $\$ 1,360,000,000$ \\
\hline Total & $\$ 3,620,000,000$ & $\$ 8,810,000,000$ & $\$ 37,200,000,000$ \\
\hline
\end{tabular}

Table 8: Economy-wide Cost of Business Downtime-Commercial Subsectors

\begin{tabular}{|l|r|r|r|}
\hline \multicolumn{1}{|c|}{ Subsector } & 20 minutes & 1 hour & 4 hours \\
\hline $\begin{array}{l}\text { Non-Refrigerated } \\
\text { Warehouses }\end{array}$ & $\$ 52,800,000$ & $\$ 84,800,000$ & $\$ 179,000,000$ \\
\hline $\begin{array}{l}\text { Refrigerated } \\
\text { Warehouses }\end{array}$ & $\$ 116,000,000$ & $\$ 347,000,000$ & $\$ 1,810,000,000$ \\
\hline
\end{tabular}




\begin{tabular}{|l|r|r|r|}
\hline Food sales & $\$ 371,000,000$ & $\$ 1,110,000,000$ & $\$ 5,800,000,000$ \\
\hline Food service & $\$ 383,000,000$ & $\$ 1,145,000,000$ & $\$ 5,600,000,000$ \\
\hline Mercantile & $\$ 151,000,000$ & $\$ 1,110,000,000$ & $\$ 3,260,000,000$ \\
\hline Lodging & $\$ 18,200,000$ & $\$ 50,100,000$ & $\$ 135,000,000$ \\
\hline Service & $\$ 294,000,000$ & $\$ 623,000,000$ & $\$ 1,860,000,000$ \\
\hline Health care & $\$ 112,000,000$ & $\$ 142,000,000$ & $\$ 205,000,000$ \\
\hline Offices & $\$ 323,000,000$ & $\$ 409,000,000$ & $\$ 594,000,000$ \\
\hline Education & $\$ 21,000,000$ & $\$ 79,100,000$ & $\$ 299,000,000$ \\
\hline Public Order & $\$ 55,200,000$ & $\$ 91,300,000$ & $\$ 217,000,000$ \\
\hline
\end{tabular}

Table 9: Economy-wide Cost of Business Downtime-Industrial Subsectors

\begin{tabular}{|c|c|c|c|}
\hline Subsector & 20 minutes & 1 hour & 4 hours \\
\hline Food products & $\$ 180,000,000$ & $\$ 573,000,000$ & $\$ 1,920,000,000$ \\
\hline Tobacco manufacturing & $\$ 2,960,000$ & $\$ 4,910,000$ & $\$ 21,700,000$ \\
\hline Textile mill products & $\$ 71,400,000$ & $\$ 118,000,000$ & $\$ 524,000,000$ \\
\hline $\begin{array}{l}\text { Apparel and other } \\
\text { finished products made } \\
\text { from fabrics }\end{array}$ & $\$ 11,400,000$ & $\$ 34,200,000$ & $\$ 141,000,000$ \\
\hline Wood products & $\$ 17,100,000$ & $\$ 32,100,000$ & $\$ 105,000,000$ \\
\hline Furniture and fixtures & $\$ 43,720,000$ & $\$ 90,030,000$ & $\$ 220,000,000$ \\
\hline $\begin{array}{l}\text { Paper and allied } \\
\text { products }\end{array}$ & $\$ 222,000,000$ & $\$ 245,000,000$ & $\$ 588,000,000$ \\
\hline Printing and publishing & $\$ 29,600,000$ & $\$ 55,600,000$ & $\$ 168,000,000$ \\
\hline Chemical products & $\$ 167,000,000$ & $\$ 321,000,000$ & $\$ 1,760,000,000$ \\
\hline Oil and coal products & $\$ 38,100,000$ & $\$ 73,400,000$ & $\$ 402,000,000$ \\
\hline $\begin{array}{l}\text { Rubber and } \\
\text { miscellaneous plastic } \\
\text { products }\end{array}$ & $\$ 22,200,000$ & $\$ 35,800,000$ & $\$ 128,000,000$ \\
\hline $\begin{array}{l}\text { Leather and leather } \\
\text { products }\end{array}$ & $\$ 0$ & $\$ 989,000$ & $\$ 12,600,000$ \\
\hline $\begin{array}{l}\text { Stone, clay, glass, and } \\
\text { concrete products }\end{array}$ & $\$ 65,400,000$ & $\$ 163,000,000$ & $\$ 649,000,000$ \\
\hline $\begin{array}{l}\text { Primary metal } \\
\text { industries }\end{array}$ & $\$ 143,000,000$ & $\$ 229,000,000$ & $\$ 484,000,000$ \\
\hline $\begin{array}{l}\text { Fabricated metal } \\
\text { products }\end{array}$ & $\$ 99,500,000$ & $\$ 199,000,000$ & $\$ 916,000,000$ \\
\hline Industrial machinery & $\$ 71,000,000$ & $\$ 127,000,000$ & $\$ 434,000,000$ \\
\hline Electrical equipment & $\$ 79,600,000$ & $\$ 151,000,000$ & $\$ 455,000,000$ \\
\hline $\begin{array}{l}\text { Transportation } \\
\text { equipment }\end{array}$ & $\$ 259,000,000$ & $\$ 638,000,000$ & $\$ 4,990,000,000$ \\
\hline $\begin{array}{l}\text { Instruments and related } \\
\text { products }\end{array}$ & $\$ 26,400,000$ & $\$ 47,300,000$ & $\$ 162,000,000$ \\
\hline $\begin{array}{l}\text { Miscellaneous } \\
\text { manufacturing } \\
\text { industries }\end{array}$ & $\$ 43,300,000$ & $\$ 34,800,000$ & $\$ 125,000,000$ \\
\hline
\end{tabular}


Figure 11: Total Industrial Sector Outage Costs after 20 Minutes: \$1.6 Billion

Total Industrial Sector Outage Costs after 20 Minutes: $\$ 1.6$ billion

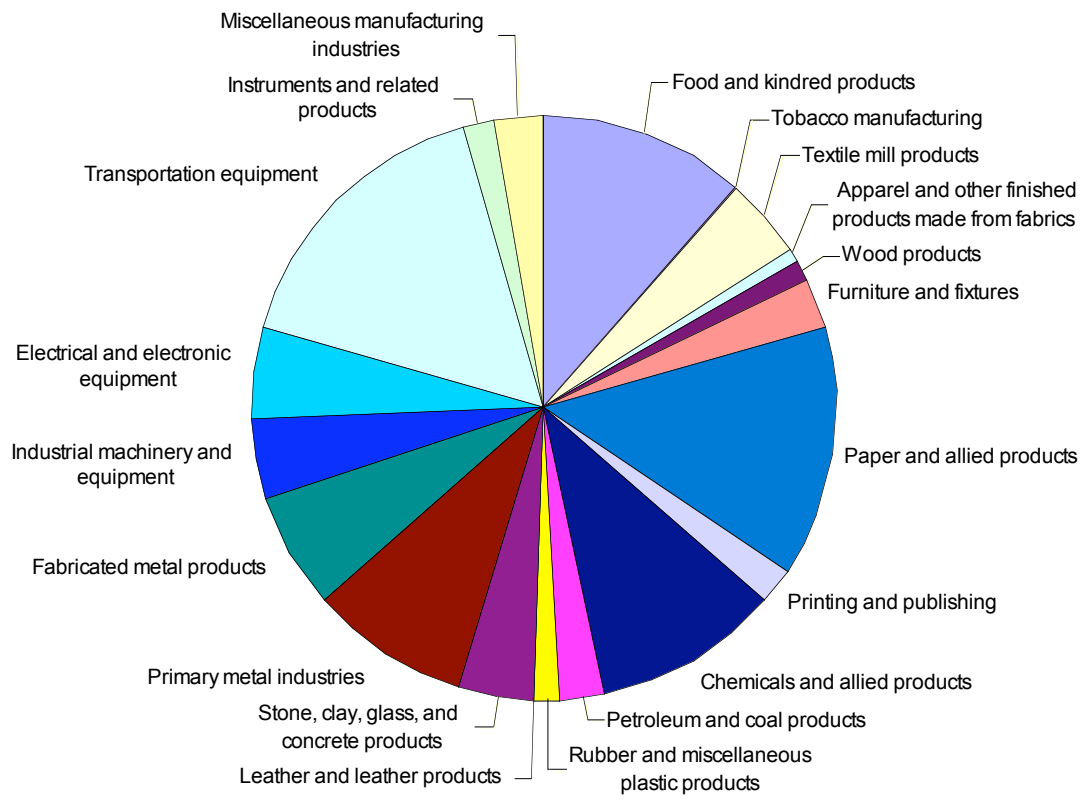

Figure 12: Total Industrial Sector Outage Costs after 4 Hours: \$14.2 Billion

Total Industrial Sector Outage Costs after 4 Hours: $\$ 14.2$ billion

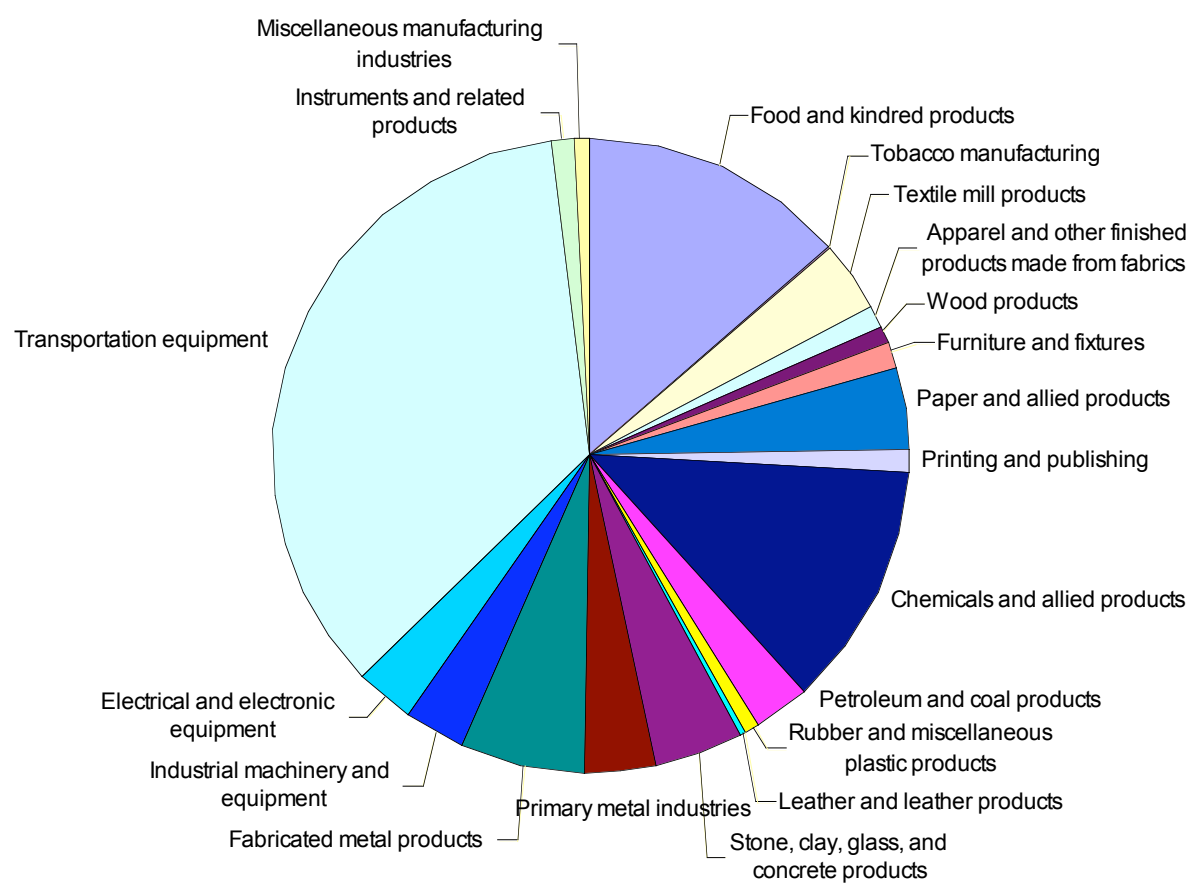




\section{REFERENCES}

${ }^{1}$ KPMG website, http://www.kpmg.com/About/

2 "Managing Business Continuity: Twenty-First Century Challenges for Competitiveness," KPMG article, 2003, available online at http://www.kpmg.com.au/aci/docs/bus-continuity.pdf

3 “The True Cost of Downtime," Bill Merchantz, Contingency Planning \& Management magazine, Volume VII, Number 4 May/June, 2002.

${ }^{4}$ June 2006 phone interview with Julian Krudritsky, Executive Director of The Uptime Institute.

5 "A Framework and Review of Customer Outage Costs: Integration and Analysis of Electric Utility Outage Cost Surveys,” LBL paper, November 2003, available at http:/eetd.lbl.gov/ea/EMS/EMS pubs.html

6 "Electrical Power Interruption Cost Estimates for Individual Industries, Sectors, and U.S. Economy," Balducci, P., et al., PNNL, February 2002.

7 "Scoping Study on Trends in the Economic Value of Electricity Reliability to the U.S. Economy," Eto, J., et al., LBNL, June 2001.

${ }^{8}$ Inflation Conversion Factors, http://oregonstate.edu/dept/pol sci/fac/sahr/sahr.htm\# Download

Conversion Factors 1, accessed May 26, 2005.

${ }^{9}$ Electric Power Annual, EIA, November, 2005.

10 "Understanding the Cost of Power Interruptions to U.S. Electricity Consumers," LaCommare, K., and Eto, J., LBNL, September 2004.

11 "Electrical Power Interruption Cost Estimates for Individual Industries, Sectors, and U.S. Economy," Balducci, P., et al., PNNL, February 2002.

12 "Scoping Study on Trends in the Economic Value of Electricity Reliability to the U.S. Economy," Eto, J., et al., LBNL, June 2001.

${ }^{13}$ Ibid.

14 "A Framework and Review of Customer Outage Costs: Integration and Analysis of Electric Utility Outage Cost Surveys," LBNL, November 2003, available at http://eetd.lbl.gov/ea/EMS/EMS pubs.html

15 "Cost of Power Interruptions to Electricity Consumers in the United States," LBNL, February 2006, available online at http://eetd.lbl.gov/ea/EMS/EMS pubs.html )

16 "The Economic Impacts of the August 2003 Blackout," Electricity Consumers Resource Council (ELCON), 2004.

17 "An Analysis of the Consequences of the August 14th 2003 Power Outage and its Potential Impact on Business Strategy and Local Public Policy,” mirifex and REI@Weatherhead, February 2004.

${ }^{18} \mathrm{http}: / /$ www.afdom.org/

19 http://www.solarstorms.org/ICFBlackout2003.pdf

${ }^{20} \mathrm{http}$ ://www.bizjournals.com/bizresources/toolbox/topics/home office/commercial insurance.html

21 "An Analysis of the Consequences of the August 14th 2003 Power Outage and its Potential Impact on Business Strategy and Local Public Policy,” mirifex and REI@Weatherhead, February 2004.

22 "Understanding the Cost of Power Interruptions to U.S. Electricity Consumers," LaCommare, K., and Eto, J., LBNL, September 2004. 